\title{
STRATEGI PERTUMBUHAN UNILEVER INDONESIA DALAM MEWUJUDKAN NILAI BERKELANJUTAN
}

\author{
Muhammad Husni Mubarok \\ Jurusan Syariah, Sekolah Tinggi Ilmu Agama Islam Negeri Kudus \\ (mr.husni99@gmail.com)
}

\begin{abstract}
This study aims to determine the strategy that used by Unilever Indonesia in realizing sustainable value so as to make Unilever Indonesia won the Capital Market Award for Best Listed Company. The results obtained showed that the strategy used by the company is refocused on the core businessthe categories and products that drive profitability. In addition, the company also creates unbeatable value for their customers by tailoring quality and price of products to match their needs and preferences which consists of 26 brands in home and personal line-up and 14 brands in foods and refreshment. Sustainable value obtained through profitable volume growth, cost leverage, efficiency, innovation and marketing investment. For Unilever Indonesia, sustainability is central to their growth model. Indonesia is facing numerous social and environmental challenges, notably poverty, health, nutrition, resource sustainability, waste management and climate change. Profitable volume growth is driven by investment in innovation and brands to deliver products which 2 billion consumers use every day.
\end{abstract}

Keywords: sustainable value, growth strategy, unilever Indonesia.

\section{A. Pendahuluan}

Unilever Indonesia merupakan perusahaan yang peduli dalam menghadapi berbagai masalah sosial dan lingkungan seperti permasalahan kemiskinan, sumber daya lestari, nutrisi, perubahan iklim, kesehatan, dan pengelolaan limbah. Perumusan strategi pertumbuhan korporat menjadi hal yang penting bagi perusahaan dalam hal 


\section{Husni Mubarok}

mengambil keputusan untuk menyelaraskan antara kondisi lingkungan eksternal yang terjadi di sekitar perusahaan, dengan sumber daya, dan kapabilitas yang dimiliki yang menjadi kopetensi inti, serta harapan dan tujuan yang ingin dicapai perusahaan yang akan datang.

Dalam situasi lingkungan persaingan pasar bebas yang penuh dinamika ini, manajemen dituntut untuk menciptakan nilai yang berkelanjutan bagi perusahaan yang mampu memberikan kontribusi yang memuaskan kepada seluruh pemangku kepentingan baik kepada pelanggan, karyawan, penanam modal, pemasok, penyalur maupun pesaing. Nilai yang berkelanjutan tersebut menjadi hal yang penting, terutama di saat keadaan makro ekonomi Indonesia tidak bisa terlepas dari volatilitas yang terjadi seperti melemahnya nilai rupiah, adanya perlambatan dalam pertumbuhan pasar, adanya pengaruh ekonomi global yang tidak menentu.

Dengan berkembangnya konteks pesaingan antar bisnis dalam lingkungan persaingan yang sangat ketat, perusahaan dituntut untuk mengembangkan dan mengimplementasikan strategi yang dapat mengantisipasi terhadap kecenderungan-kecenderungan baru untuk mencapai dan mempertahankan posisi bersaing maupun nilai keunggulan yang berkelanjutan. Daya saing perusahaan tidak bisa lepas dari kondisi yang mencakup pelaksanaan bisnis, penyeimbangan kualitas, baik dalam bentuk barang dan jasa serta kebutuhan unik dari berbagai basis pelanggan (Coulter, 2002). Iklim makro ekonomi yang sulit memberikan dampak yang signifikan terutama dengan adanya inflasi yang tinggi dan kenaikan tingkat suku bunga.

Kepedulian Unilever Indonesia terhadap lingkungan seperti komitmen untuk mengurangi efek gas rumah kaca, mengurangi limbah terkait dengan pola penggunaan produk oleh konsumen menjadikan Unilever Indonesia sangat menarik untuk diteliti dan dibahas lebih lanjut. Disamping itu, alasan pemilihan Unilever Indonesia sebagai obyek penelitian dalam penelitian ini karena secara berturut-turut Unilever Indonesia memenangkan penghargaan kapitalisasi pasar sebagai perusahaan yang terbaik dari perusahaan-perusahaan dengan kapitalisasi pasar lebih dari sepuluh triliun rupiah. Strategi Unilever Indonesia dalam menciptakan nilai yang dilakukan dengan memperkuat mata rantai distribusi dan memperkokoh bauran produk menjadi hal yang penting untuk dibahas. 
Nilai keunggulan bersaing berkelanjutan merupakan segala sesuatu yang dilakukan dengan sangat baik oleh perusahaan dibandingkan dengan yang dilakukan oleh pesaingnya. Ketika sebuah perusahaan dapat melakukan sesuatu dengan lebih baik sedangkan perusahaan lainnya tidak dapat, atau memiliki sesuatu yang tidak dimiliki oleh perusahaan lain sehingga para pesaing menginginkannya, maka hal tersebut menggambarkan keunggulan kompetitif perusahaan dan menjadi hal menarik yang harus dibahas dalam upaya mewujudkan nilai berkelanjutan bagi Unilever Indonesia untuk terus tumbuh di pasar.

\section{B. Landasan Teori}

Unilever Indonesia menerapkan strategi diversifikasi produk dengan memproduksi, memasarkan dan mendistribusikan barangbarang konsumsi yang meliputi sabun, deterjen, margarin, makanan berinti susu, es krim, produk-produk kosmetik, minuman dengan bahan pokok teh dan sari buah. Unilever Indonesia memiliki 8 pabrik dengan 40 jenis produk. Strategi yang dilakukan oleh perseroan merupakan upaya untuk menciptakan sinergi keuangan yang dilakukan dengan menyeimbangkan antara bisnis yang memiliki kas besar tapi peluang rendah dengan bisnis yang mempunyai kas kecil tapi peluang tinggi, atau antara bisnis yang sarat utang dengan bisnis yang bebas utang (Markides, 1997: 79-98). Pertimbangan utama strategi ini adalah potensi laba yang tinggi dan permintaan akan sumber daya yang minimal.

Penggunaan istilah strategi pertumbuhan seringkali untuk mendiskripsikan dan menentukan tujuan yang ingin dicapai perusahaan melalui banyaknya bisnis yang ingin dimasuki, menghasilkan keputusan dan kebijakan untuk mencapai tujuan tersebut serta mendefinisikan cakupan bisnis melalui portofolio bisnis yang dipilih oleh perusahaan. Strategi korporat merupakan perencanaan jangka panjang secara menyeluruh mengenai bisnis apa saja yang ingin dimiliki oleh perusahaan dengan cara membeli beragam bisnis, dan apa yang diinginkan dalam bisnis tersebut sebagai bagian dari korporat, serta bagaimana cara perusahaan menciptakan nilai konfigurasi dalam menciptakan sinergi dari aktivitas multi bisnisnya (Thompson \& Strickland, 2003:50).

Strategi korporat dapat dirumuskan dalam level manajemen yang tertinggi. Eksekutif senior perusahaan biasanya yang mempunyai tanggung jawab untuk memutuskan strategi korporat dan memilih 


\section{Husni Mubarok}

antara apakah merekomendasikan pelaksanaannya dari level manajemen yang lebih rendah. Pimpinan unit bisnis juga merupakan kunci yang mempengaruhi keputusan strategis terutama yang berkaitan dengan bisnis yang mereka pimpin. Strategi korporat terdiri dari strategi yang dapat diaplikasikan sesuai dengan siklus korporat yang dihadapi. Pada umumnya perusahaan dimulai dengan strategi pertumbuhan, kemudian berkembang hingga mencapai stabil.

Perjalanan produk margarin blue band dan sabun mandi lux dipasarkan di Indonesia sejak tahun 1936. Pada tahun 1990 perusahaan melakukan pertumbuhan internal dengan mendirikan pabrik perawatan personal. Disamping itu, perusahaan juga mulai melakukan diversifikasi dengan memasuki bisnis teh dengan mengakuisisi SariWangi. Pada tahun 1992 melakukan ekspansi usahanya dengan membuka pabrik es krim Wall's. Hal tersebut diiringi dengan munculnya Conello dan Paddle Pop pertama kali di pasar. Implementasi strategi ini bisa juga dilakukan dengan menambah unit usaha strategis yang menghasilkan barang dan jasa yang sama dengan yang sebelumnya telah dimiliki (Basri, 2005: 81). Hal ini bisa dilakukan dengan akuisisi, yaitu dengan membeli perusahaan lain yang menghasilkan produk yang sama yang sebelumnya menjadi pesaing perusahaan.

Pengembangan usaha dilanjutkan dengan memasuki bisnis kecap dengan mengakuisisi Bango pada tahun 2000. Kemudian pada tahun 2004 melakukan akuisisi Knorr Indonesia dari Unilever Overseas Holding Ltd dan memindahkan pabrik produk perawatan rambut. Perusahaan telah melangkah dengan ekspansi tersebut, perusahaan tidak lagi hanya beroperasi dalam bisnis intinya (Zook, 2004: 35-74). Strategi ini merupakan jenis strategi pertumbuhan yang dilakukan dengan berkonsentrasi pada industri sekarang, dengan maksud mempertahankan posisi perusahaan dalam industri yang sama dengan memperluas pangsa pasar dan memperkuat posisinya.

Proses diversifikasi terus berlanjut, ditandai dengan membangun pabrik perawatan kulit terbesar se-Asia pada tahun 2008. Pada tahun tersebut perusahaan juga menambah diversifikasi bisnisnya dengan memasuki bisnis minuman sari buah dengan mengakuisisi merek Buavita dan Gogo. Strategi ini menghasilkan pertumbuhan melalui akuisisi (Suwarsono, 2008: 298), yang mempunyai lini bisnis yang sama, dan memberikan perusahaan akses ke pasar dan teknologi yang baru.

Perusahaan berusaha berkembang dengan memperluas pasar memasuki pasar baru dengan menggunakan produk dan atau jasa yang 
baru. Formulasi strategi pada Unilever Indonesia dilakukan dengan fokus tanpa henti pada bisnis inti yaitu dengan meningkatkan kualitas kehidupan, meningkatkan kesehatan dan kesejahteraan, mengurangi dampak lingkungan, meningkatkan penghidupan. Pertimbangan yang mendorong perusahaan untuk melakukan strategi ini (David, 2005: 231) adalah keinginan untuk menjamin produksi dengan meningkatkan stabilitas dan kepastian pasokan, baik dalam hal kuantitas, kualitas maupun kontinuitas.

Disamping itu, upaya meningkatkan kebiasaan hidup sehat bagi satu miliar penduduk, upaya untuk meningkatkan cita-cita dan kualitas gizi dari seluruh produk menjadi hal yang penting untuk dibahas. Menggunakan pilihan diversifikasi pasar-produk dengan cara melakukan ekspansi dalam pasar maupun produk yang baru. Pada titik ini, perusahaan berubah dari bisnis tunggal menjadi multi bisnis, karena perusahaan sudah memasuki pada industri yang berbeda.

Strategi diversifikasi pasar-produk merupakan strategi pertumbuhan dengan menganeka-ragamkan jenis usaha. Perusahaan berusaha berkembang dengan memperluas pasar memasuki pasar baru dengan menggunakan produk dan atau jasa yang baru. Menggunakan pilihan diversifikasi pasar-produk dengan cara melakukan ekspansi dalam pasar maupun produk yang baru. Pada titik ini, perusahaan berubah dari bisnis tunggal menjadi multi bisnis, karena perusahaan sudah memasuki pada industri yang berbeda (Purnomo \& Zulkieflimansyah, 2005: 76).

Strategi diversifikasi konsentris merupakan strategi konsentrasi terkait dengan masuk pada bisnis baru yang masih terkait atau memiliki kesesuaian yang tinggi dengan bisnis yang dilakukan perusahaan pada saat ini. Strategi diversifikasi konsentris menekankan pada kesamaan dalam hal pasar, saluran distribusi, produk dan teknologi, dengan sinergi pasar produk. Diversifikasi konsentris terjadi jika perusahaan melakukan ekspansi usaha dengan menambah unit usaha baru, baik dengan cara pertumbuhan internal maupun akuisisi, pada bidang usaha yang masih memiliki keterkaitan, baik langsung maupun tidak langsung dengan bisnis yang dimiliki saat ini.

Keunggulan bersaing berkelanjutan juga dapat dilihat dari sudut pandang kapabilitas dan sumberdaya yang dimilikinya yang berharga dan menghasilkan kompetensi inti. Sinergi dari pengelolaan yang baik atas apa yang menjadi kekuatan perusahaan, serta pemilihan untuk menjalankan strategi yang dipilih akan menghasilkan keunggulan 


\section{Husni Mubarok}

bersaing berkelanjutan bagi perusahaan dalam menghadapi para pesaingnya (Ernie \& Kurniawan, 2005: 144). Strategi ini bertujuan agar perusahaan mendapatkan sinergi, efisiensi, atau pengaruh pasar yang lebih besar serta membagi resiko melalui penggunaan bersama sumber daya yang dimiliki tapi bukan saling ketergantungan. Penekanan strategi ini adalah membangun kapabilitas sumber daya kunci dan kompetensi inti perusahaan.

\section{Pembahasan}

\section{Nilai Berkelanjutan Unilever Indonesia}

Strategi bisnis Unilever Indonesia dalam menciptakan nilai bagi pemegang saham melalui model bisnis yang memadukan tiga elemen utama yaitu merek, operasional dan karyawan. Adapun cara yang dilakukan Unilever Indonesia dalam meningkatkan keuntungan melalui pertumbuhan volume yang menguntungkan, keunggulan biaya dan efisiensi, inovasi dan investasi pemasaran. Unilever Indonesia meraih pertumbuhan dan mengukuhkan posisinya di pasar dengan berfokus pada peningkatan kesehatan dan kesejahteraan masyarakat, mengurangi dampak lingkungan dan meningkatkan penghidupan.

Keunggulan Unilever Indonesia akan memungkinkan perusahaan untuk menciptakan nilai lebih untuk pelanggannya dan perusahaan dapat memperoleh keuntungan yang lebih tinggi. Nilai yang dihasilkan dari strategi bersaing perusahaan dapat menjelaskan posisi perusahaan dalam industri sebagai pemimpin dalam hal biaya atau sebagai pemimpin dalam hal keunikannya (Hunger \& Wheelen, 2003: 24). Unilever memiliki rangkaian produk yang mencakup produk perawatan personal dan rumah serta produk makanan dan minuman.

Nilai yang harus diciptakan dalam konteks persaingan adalah sesuatu yang dicari oleh konsumen seperti harga yang murah, produk yang berkualitas, merek yang terkenal, keunikan fitur dan atribut produk yang khas, dan pelayanan purna jual. Penciptaan nilai tersebut dapat meningkatkan nilai perusahaan secara keseluruhan dengan meningkatnya pangsa pasar dan penjualan serta bisa memberi dampak pada peningkatan harga saham.

Nilai berkelanjutan yang diperoleh Unilever Indonesia melalui kekuatan dalam inovasi yang telah dibuktikan dengan adanya peluncuran serangkaian produk yang secara nyata telah mengalami kesuksesan. Hal ini membuktikan bahwa perseroan telah meraih keunggulan dalam berbagai hal, diantaranya dengan memperkuat 
kembali para mitra distribusinya dan mengembangkan pasar-pasar baru secara agresif. Untuk itu, pentingnya membahas strategi yang dilakukan oleh perseroan dalam mewujudkan nilai yang berkelanjutan bagi pemegang kepentingan dan masyarakat pada umumnya.

Strategi inovasi yang dilakukan Unilever Indonesia merupakan bentuk strategi untuk meraih margin premium berkaitan dengan penciptaan dan penerimaan pelanggan atas produk atau jasa baru (Pearce \& Robinson, 2007: 273). Inovasi tersebut merupakan cara yang digunakan perusahaan untuk menciptakan sumber daya baru, memproduksi keunggulan kompetitif atau mendayagunakan sumber daya yang sudah ada dengan meningkatkan potensinya untuk menghasilkan keuntungan diatas rata-rata. Nilai yang berkelanjutan diciptakan melalui inovasi baru dalam pelembab muka dan pelembab dalam format gel pertama yang ditawarkan oleh merek pencerah kulit serta pelembab wajah. Perusahaan juga membuat terobosan dalam perawatan tubuh yang memanjakan konsumen. Citra Wakame Gel merupakan merek perawatan tubuh pertama yang menawarkan sensasi ringan dalam format gel yang menyejukkan.

Peningkatan daya saing Unilever Indonesia dilakukan dengan menggunakan basis utama yaitu inovasi yang superior dimana yang satu dengan yang lainnya mempunyai keterkaitan yang tinggi (Hill \& Jones, 1995). Strategi Unilever Indonesia dalam mengembangkan usahanya dilakukan melalui berbagai inovasi dalam penganeka ragaman portofolio merek yang dibagi dalam dua kelompok, yaitu kategori produk keperluan rumah tangga dan perawatan tubuh yang terdiri dari 26 jenis produk yang disiapkan oleh perusahaan untuk membantu konsumen dalam menikmati hidup sehari-hari dan kelompok makanan dan minuman yang terdiri dari 14 jenis produk yang dapat memanjakan konsumen dengan pilihan rasa yang nikmat, bergizi dan berkualitas tinggi.

Kesuksesan dan keberhasilan perusahaan dalam melipatgandakan bisnisnya dan mengembangkan usahanya ditandai dengan banyaknya omset yang dicatat lebih dari 2 miliar euro dalam kurun waktu lima tahun. Perusahaan meluncurkan produk Sunligt pada tahun 2013 dalam rangka memperingati 80 tahun perjalanan Unilever Indonesia untuk memberikan inspirasi bagi masyarakat dalam menciptakan masa depan yang lebih cerah. Perusahaan yang melakukan keputusan strategis dan menerapkannya dengan cepat, inovatif serta mampu menghasilkan produk dan jasa yang berkualitas, 


\section{Husni Mubarok}

memungkinkan perusahaan untuk mencapai daya saing strategis di pasar domestik dan global serta merupakan pesaing yang kuat dan memiliki peluang menghasilkan laba diatas rata-rata (Hitt dkk, 2001).

Nilai dan manfaat yang diciptakan oleh perusahaan melalui inovasi yang berkelanjutan seperti pureit yang dipercaya oleh pasar sebagai alat pemurni air. Perusahaan terus melakukan strategi pengembangan pasar dengan meluncurkan Marvella dalam portofolio pureit. Segmentasi pasar yang dituju adalah konsumen berpenghasilan lebih tinggi dengan memanfaatkan teknologi UV untuk menghasilkan pemurnian yang lebih efektif dan canggih yang dipasang di dinding. Penyempurnaan dalam setiap inovasi guna mendorong pertumbuhan dan memenangkan persaingan di pasar.

Strategi yang dilakukan oleh Unilever Indonesia untuk mendapatkan pengendalian atas para pesaing yang berada pada rangkaian produk-pemasaran yang sama oleh beberapa perusahaan yang lebih kecil dalam industri yang didominasi oleh pesaing besar. Strategi ini dikatakan integrasi ekspansif dan memiliki daya tarik yang tinggi (Weston, 2001: 87-98), karena produk baru yang dihasilkan oleh unit usaha strategis baru memiliki keterkaitan dengan produk yang diproduksi sebelumnya dan keterkaitan tersebut dapat berkembang pada aspek pasar, produksi, teknologi, dan sumber daya manusia.

\section{Keunggulan Berkelanjutan Unilever Indonesia}

Keunggulan kompetitif merupakan segala sesuatu yang dilakukan dengan sangat baik oleh perusahaan dibandingkan dengan yang dilakukan oleh pesingnya. Ketika sebuah perusahaan dapat melakukan sesuatu dengan lebih baik sedangkan perusahaan lainnya tidak dapat, atau memiliki sesuatu yang tidak dimiliki oleh perusahaan lain sehingga para pesaing menginginkannya, maka hal tersebut menggambarkan keunggulan kompetitif perusahaan.

Keunggulan kompetitif yang berkelanjutan dapat dilakukan dengan cara terus menerus beradaptasi dengan mengikuti tren yang ada di pasar, menyesuaikan isu persaingan serta meningkatkan kapabilitas, kompetensi inti dan sumber daya internal. Perusahaan dapat merumuskan dan mengembangkan strategi dimana pesaing tidak mampu mengimplementasikannya, melakukan sesuatu yang tidak dapat dilakukan oleh pesaing dalam jangka panjang.

Unilever Indonesia dalam mewujudkan pertumbuhan berkelanjutan dengan melibatkan secara langsung para pemangku 
kepentingan seperti menjalin kerjasama dengan sejumlah pemasok utama yang meliputi petani kedelai hitam, petani gula kakao dan petani teh dalam usaha meningkatkan hasil panen melalui praktik perkebunan yang lestari. Strategi untuk meningkatkan pengendalian atas pasokan bahan baku, sumber daya atau jasa. Ini terjadi jika perusahaan menguasai atau menjalin kerjasama dengan pemasoknya dengan menjadi pemasoknya sendiri (Kuncoro, 2006: 115).

Keunggulan kompetitif berkelanjutan suatu perusahaan dapat menciptakan daya saing ketika perusahaan tersebut mempunyai sesuatu yang tidak dimiliki pesaing, melakukan sesuatu yang lebih baik dan lebih unik dari perusahaan lain dalam pasar, atau mampu melakukan sesuatu yang tidak mampu dilakukan oleh perusahaan lain dalam kompetisi di persaingan bisnis (Hendrawan dkk, 2003). Hal ini dibuktikan dengan diperolehnya penghargaan pasar modal oleh Unilever Indonesia sebagai perusahaan yang memiliki kapitalisasi pasar diatas sepuluh triliun rupiah. Penghargaan tersebut dari otoritas jasa keuangan, bursa efek Indonesia, kliring penjaminan efek Indonesia dan Kustodian Sentral Efek Indonesia.

Keunggulan kompetitif berkelanjutan dilakukan untuk memperoleh keuntungan diatas rata-rata. Keuntungan diatas rata-rata tersebut merupakan keuntungan yang diperoleh melebihi apa yang diharapkan akan diperoleh investor dibandingkan investasi lain dengan risiko yang sama. Keuntungan diatas rata-rata menunjukkan keuntungan yang dihasilkan dengan komparasi kinerja yang melebihi perusahaan lain dalam industri yang sama. Hal ini didukung dengan diperolehnya penghargaan kecelakaan nihil oleh menakertrans kepada Unilever Indonesia.

Kontribusi Unilever Indonesia dalam menghindarkan dampak lingkungan yang buruk dengan mengurangi sampah dan limbah pabrik, mengurangi biaya operasional, meningkatkan pengaruh sosial yang positif melalui kerjasama dengan para pemasok sumber pertanian lestari dengan tujuan meningkatkan penghidupan mereka. Komitmen perseroan dalam mewujudkan nilai yang berkelanjutan melalui program peningkatan kesejahteraan dan bantuan untuk meningkatkan kebiasaan hidup yang sehat, mengurangi dampak lingkungan dengan berkomitmen untuk mengurangi efek gas rumah kaca dari portofolio produk yang dimiliki.

Keunggulan bersaing yang berkelanjutan yang dimiliki oleh Unilever Indonesia diantaranya yaitu keunggulan diferensiasi dan 


\section{Husni Mubarok}

keunggulan biaya. Suatu keunggulan bersaing yang berkelanjutan muncul ketika sebuah perusahaan dapat menghasilkan produk yang sama dengan yang dihasilkan pesaingnya dengan biaya yang lebih rendah, atau menghasilkan produk/jasa yang berbeda dan lebih baik dari yang dihasilkan pesaingnya (Thompson \& Strickland, 2003: 150). Bentuk nilai yang berkelanjutan yang diperoleh Unilever Indonesia didukung dengan pemberian layanan pemeriksaan gigi gratis kepada lebih dari lima ribu orang selama enam bulan pertama di pusat layanan gigi pepsodent.

Strategi pengembangan pasar dalam divisi perawatan personal melalui strategi penetrasi pasar yang dilakukan secara terus menerus dan inovasi untuk meningkatkan pangsa pasar. Rangkaian produk pond's melakukan strategi pertumbuhan dengan meluncurkan varianvarian baru dan kemasan baru berukuran $10 \mathrm{ml}$. Begitu juga tresemme dengan meluncurkan keratin smooth, Vaseline dengan meluncurkan format baru, vaseline body serum dan sekaligus menambah varian baru dapat memimpin pertumbuhan dalam produk perawatan tubuh. Barang/jasa yang diinginkan bersifat terspesialisasi, sehingga sedikit alternatif pemasok yang mungkin ada dan memungkinkan kontraktor mengambil keuntungan dan menyebabkan meningkatnya biaya. Transaksi harus sering terjadi, yang memungkinkan kontraktor meminta perlakuan istimewa dan akan meningkatkan biaya (Williamson, 1991).

Keunggulan perusahaan dalam merespon pasar yang berubahubah, tidak pasti, kompleks dan ambigu sangat tergantung dalam keseluruhan dalam menjalankan seluruh aktivitas rantai nilai bisnis dari awal sampai akhir: mulai dari pengadaan bahan mentah sampai tersedianya produk di rak-rak toko. Strategi ini membuat berbeda dari strategi pengembangan produk yang memperpanjang siklus hidup dari produk yang telah ada. Hanya sedikit perusahaan yang menjadikan inovasi sebagai cara yang mendasar untuk membuat relasi dengan pasarnya (Tedjo \& Udan, 2005: 128).

Keuntungan diatas rata-rata menjadi harapan para pemegang kepentingan terutama investor dalam melakukan analisis investasi. Dalam jangka panjang perusahaan akan menarik investasi dari perusahaan yang menghasilkan keuntungan dibawah rata-rata dan akan memilih investasi dalam perusahaan yang menghasilkan keuntungan diatas rata-rata dengan minimal menghasilkan pada rata-rata industri. Bentuk keunggulan dari produk Unilever Indonesia adalah molto ultra 
pure dengan formula inovasinya yang bisa membuat pakaian tiga kali lebih lembut dibanding pelembut cucian biasa.

\section{Kesimpulan}

Suatu perusahaan dikatakan mempunyai nilai keunggulan bersaing berkelanjutan ketika perusahaan tersebut memiliki sesuatu yang tidak dimiliki oleh pesaing, melakukan sesuatu yang lebih baik dari perusahaan lain, atau mampu melakukan sesuatu yang tidak mampu dilakukan oleh perusahaan lain. Keungulan kompetitif menjadi suatu kebutuhan penting bagi kesuksesan perusahaan dalam jangka panjang dan kelangsungan hidup perusahaan di masa mendatang.

Nilai keunggulan bersaing berkelanjutan sangat penting untuk didapatkan, dimiliki, dijaga dan dipertahankan demi keberhasilan jangka panjang dari suatu perusahaan. Mengejar keunggulan kompetitif akan mengarahkan perusahaan kepada kesuksesan persaingan. Perusahaan tidak cukup hanya memiliki keunggulan kompetitif, karena pada umumnya keunggulan kompetitif hanya bertahan untuk periode tertentu diakibatkan karena ditiru oleh pesaing atau melemahnya keunggulan tersebut.

Perusahaan harus berusaha mencapai keunggulan kompetitif berkelanjutan yang berarti menunjukkan upaya perusahaan dalam jangka panjang yang mampu mempertahankan posisi keunggulan kompetitif dalam industri. Keunggulan kompetitif berkelanjutan akan tercapai bila suatu perusahaan berhasil memformulasikan dan mengimplementasikan sutu strategi yang menciptakan nilai bagi konsumen dalam jangka panjang dan susah ditiru oleh pesaing.

Nilai yang harus diciptakan dalam konteks persaingan adalah sesuatu yang dicari oleh konsumen seperti harga yang murah, produk yang berkualitas, merek yang terkenal, keunikan fitur dan atribut produk yang khas, dan pelayanan purna jual. Penciptaan nilai tersebut dapat meningkatkan nilai perusahaan secara keseluruhan dengan meningkatnya pangsa pasar dan penjualan serta bisa memberi dampak pada peningkatan harga saham. Nilai yang diperoleh oleh Unilever Indonesia dibuktikan dengan sejumlah penghargaan yang didapatkannya. 
Unilever Indonesia berhasil mendapatkan penghargaan top brand sebanyak 24 jenis produk dari 40 jenis produk yang dimilikinya. Perusahaan juga meraih penghargaan kepuasan pelanggan sebanyak 5 jenis produk berdasarkan penelitian Roy Morgan. Disamping itu, perusahaan berhasil meraih penghargaan social media sebanyak 19 jenis produk ditambah penghargaan merek terbaik untuk anak-anak. Bentuk penghargaan terhadap nilai berkelanjutan yang dimiliki oleh Unilever adalah diperolehnya penghargaan kepuasan pelanggan Indonesia sebanyak 12 merek dari SWA. 


\section{DAFTAR PUSTAKA}

Basri. 2005. Bisnis Pengantar, Edisi Pertama.Yogyakarta: BPFE

Coulter, Mary. 2002. Strategic Management in Action, $2^{\text {nd }}$ ed., New Jersy: Prentice Hall.

David, Fred R. 2005. Strategic Management: Concepts and Cases, 10 ${ }^{\text {th }}$ ed. New Jersy: Pearson Education Prentice Hall.

Ernie TS \& Kurniawan S. 2005. Pengantar Manajemen, Edisi 1. Jakarta: Kencana.

Hendrawan, S. dkk. 2003. Advanced Strategic Management: Back to Basic Approach. Jakarta: Gramedia PU.

Hill, C.W.L. and G.R. Jones. 1995. Strategic Management; An Integral Approach, Boston, Houghton Mifflin Company.

Hitt, Michael A, Ireland, R. Duane, Hoskisson, Robert E. 2001. Strategic Management: Competitiveness and Globalization $4^{\text {th }}$ Edition; Concepts. Singapore: Thompson Learning

Hunger, J.David \& Wheelen, Thomas L. 2003. Strategic Management $5^{\text {th }}$ Edition. Yogyakarta: Andi.

Kuncoro, Mudrajad. 2006. Strategi Bagaimana Meraih Keunggulan Kompetitif. Jakarta: Erlangga.

Markides, Constantinos C. 1997. To Diversity or Not to Diversity dalam Harvard Business Review on Strategies for Growth, hal:79-98. Boston: Harvard Business School Press.

Pearce, J.A \& Robinson, R.B. 2007. Strategic Management: Formulation, Implementation, and Control, 10 ${ }^{\text {th }}$ Edition. New York: McGraw-Hill Companies, Inc.

Purnomo, Setiawan Hari \& Zulkieflimansyah. 2005. Manajemen Strategi: Sebuah Konsep Pengantar. Jakarta: FE UI 
Suwarsono, Muhammad 2008. Manajemen Strategik: Konsep dan Kasus. Edisi 4. Yogyakarta: UPP STIM YKPN.

Tedjo Tripomo \& Udan. 2005. Manajemen Strategi. Bandung: Rekayasa Sains.

Thompson, Jr, Arthur A \& Strickland III, A.J. 2003. Strategic Management: Concepts and Cases. Thirteenth Edition. New York: McGraw-Hill Companies, Inc.

Weston, J. Fred. 2001. Takeovers, Restructuring, \& Corporate Governance. New Jersey: Prentice Hall.

Williamson, O.E. \& Winter, S.G. 1991. The Nature of The Firm: Origins, Evolution, and Development. New York: Oxford University Press.

Zook, Chris. 2004. Beyond the Core: Expand Your Market Without Abonding Your Roots. Boston: Harvard Business School Press. 